\title{
PENGEMBANGAN MULTIMEDIA INTERAKTIF BERBASIS INKUIRI PADA MATERI SISTEM REPRODUKSI MANUSIA UNTUK MENINGKATKAN HASIL BELAJAR DAN MELATIHKAN KETERAMPILAN BERPIKIR KRITIS SISWA
}

\author{
Syahdiani ${ }^{1)}$, Soeparman Kardi $^{2}$, I G Made Sanjaya ${ }^{3)}$ \\ ${ }^{1)}$ Mahasiswa Program Studi Pendidikan Dasar, Program Pascasarjana Universitas Negeri Surabaya \\ ${ }^{2), 3)}$ Dosen Pascasarjana Prodi Pendidikan Sains Univesrtitas Negeri Surabaya \\ E-mail:dhani.fiz@gmail.com
}

\begin{abstract}
This study aims to describe the feasibility of interactive multimedia based inquiry on material Human Reproduction System to improve learning outcomes and practice students critical thinking skill. The feasibility product is measuring by validity, practically and effectiveness result. The validity product by looking expert media, and content expert valued. The practicaly instructional package showed by learning implementation, and students intrested. The effectiveness by looking at learning outcome and the diffrence between the scores of pretest and posttest achieved by the students. This research is design by instructional learning package design based on Dick and Carey model, developing design media based on ASSURE model and involved XI Science grade at SMA Negeri 1 Batu Sopang. Data from the expert of media, content, design and students intrested were obtained by using observation and test.The data was obtained analyzed by descriftif analyzes technic. The result of research show that the validity of learning material is valid category, implementation is very good category . Aspect of the student response individual user is good, with $32,13 \%$ very agree and 55,3\% agree at the real implementation. The students intrested on lerning model is good category. Learning achievment of cognitive, psychomotoric and sosial spiritual attitude aspect than increasing critical thinking skill. $\mathrm{N}$ (gain scores) analyses showed that there are average gain score increasing $0,8($ high gain). This study thus showed that interactive multimedia base on inquiry developed feasible to improve learning outcome and practice students critical thinking skills
\end{abstract}

Keywords: Interactive Multimedia, Human Reproductive System, Inqury, Learning Outcomes, Critical Thingking Skills

\begin{abstract}
Abstrak : Penelitian ini bertujuan mendeskripsikan kelayakan multimedia interaktif berbasis inkuiri materi sistem reproduksi manusia untuk meningkatkan hasil belajar dan melatih keterampilan berpikir kritis siswa SMA. Kelayakan perangkat diukur dari validitas, kepraktisan dan efektivitas. Validitas perangkat dilihat dari penilaian ahli media dan ahli materi. Kepraktisan perangkat dilihat dari keterlaksanaan pembelajaran, respon dan minat siswa. Efektivitas perangkat dilihat dari hasil belajar siswa serta perbedaan antara skor pretest dan posttest yang dicapai siswa. Penelitian ini menggunakan desain pengembangan perangkat pembelajaran dengan mengadaptasi model Dick and Carey, desain pengembangan media menggunakan model ASSURE dan melibatkan para siswa kelas XI IPA SMA Negeri 1 Batu Sopang sebagai sampel pengujian. Data uji ahli media, isi, desain, dan respon siswa dikumpulkan dengan menggunakan angket, sedangkan uji coba kepada siswa diperoleh dengan menggunakan lembar observasi dan tes. Data yang didapatkan selanjutnya dianalisis menggunakan teknik analisis deskriptif. Hasil penelitian menunjukkan bahwa validitas perangkat pembelajaran berkategori valid, keterlaksanaannya berkategori terlaksana dengan baik. Ditinjau dari aspek tanggapan siswa pengguna, media hasil pengembangan berkategori baik, dengan persentase 32,3 \% sangat setuju dan 55,3\% setuju pada implementasi di lapangan. Minat siswa pada model pembelajaran yang diterapkan berkategori baik Ketuntasan hasil belajar kognitif, psikomotor dan sikap spiritual sosial tercapai, serta peningkatan keterampilan berpikir kritis. Analisa $N($ Gain Scores) menunjukkan bahwa terdapat peningkatan gain skor rata-rata 0,8 (kategori tinggi). Dengan demikian, penelitian ini menunjukkan bahwa multimedia interaktif berbasis inkuiri yang dikembangkan layak digunakan untuk meningkatkan hasil belajar dan melatih keterampilan berpikir kritis siswa.
\end{abstract}

Kata kunci: Multimedia Interaktif, Sistem Reproduksi Manusia, Inkuiri, Hasil Belajar, Keterampilan Berpikir Kritis

\section{PENDAhuluan}

Pendidikan memegang peran utama dalam proses pengembangan sumber daya manusia. Peningkatan kualitas pendidikan merupakan suatu proses yang tidak dapat dipisahkan dengan proses peningkatan kualitas sumber daya manusia itu sendiri. Pendidikan yang merupakan kunci utama keberhasilan suatu bangsa dalam bersaing di tingkat global. Arti penting dari pendidikan adalah suatu proses pemindahan informasi dan nilai-nilai yang ada. Selama proses ini terjadi, maka 
akan terjadi perubahan dalam penalaran dan pengambilan sikap menuju hal yang lebih baik.

Tujuan pendidikan nasional yang termuat dalam UU No. 20 tahun 2003 adalah mengembangkan potensi peserta didik agar menjadi manusia yang beriman dan bertaqwa kepada Tuhan Yang Maha Esa; berakhlaq mulia, sehat, berilmu, cakap, kreatif, mandiri dan menjadi warga negara yang demokratis serta bertanggungjawab.

Pada jenjang pendidikan menengah ditransformasikan berbagai macam ilmu pengetahuan yang dapat dijadikan bekal siswa untuk mengembangkan potensi yang ada dalam dirinya. Salah satu ilmu dasar diajarkan pada jenjang pendidikan menengah adalah biologi yang merupakan suatu ilmu pengetahuan yang sangat luas cakupannya dan berhubungan erat dengan kehidupan sehari-hari.

Biologi tidak hanya berupa teori, bersifat hafalan dan pemahaman akan konsep, tetapi didalamnya juga berupa proses penerapan hingga penemuan, maka dalam proses penyampaiannya harus melibatkan siswa secara aktif. Selain itu siswa juga harus terlibat aktif dalam menemukan berbagai permasalah dengan caracara ilmiah.

Hasil studi awal dikelas XII SMAN 1 Batu Sopang tahun 2013 untuk mata pelajaran biologi dilakukan evaluasi ternyata hasil belajar yang diperoleh pada ranah pengetahuan masih belum mencapai KKM sekolah. Pada tahun pelajaran 2012/2013 dari siswa kelas XI IPA yang berjumlah 62 siswa hanya 15 siswa yang tuntas dengan nilai KKM 72 (Sumber Nilai LHBS kelas XI IPA SMAN 1 Batu Sopang tahun 2012/2013). Hal ini menimbulkan pertanyaan dimana letak permasalahan sehingga hasil belajar siswa tersebut tidak sesuai seperti yang diharapkan. Untuk mengetahui gambaran awal maka dilakukan wawancara terhadap beberapa orang siswa secara acak.

Berdasarkan hasil wawancara dengan siswa kelas XII IPA SMAN 1 Batu Sopang yang pada tahun 2012 sudah pernah mempelajari materi tersebut, diperoleh keterangan bahwa ada beberapa bagian materi pokok bahasan sistem reproduksi yang sulit dipahami oleh siswa SMA karena di dalamnya terkandung materi yang sulit dijelaskan dengan metode ceramah yaitu terutama pada bagian mekanisme gametogenesis, ovulasi, fertilisasi, kehamilan, dan juga teknologi reproduksi invitro, sehingga pemahaman siswa terhadap materi ini masih belum optimal.

Pola pembelajaran materi sistem reproduksi manusia di kelas XI IPA masih didominasi dengan metode ceramah oleh guru serta kurang memanfaatkan media pembelajaran yang berbasis teknologi informasi dan komunikasi. Meskipun fasilitas untuk pembelajaran dengan memanfaatkan teknologi informasi dan komunikasi sudah memadai. Adanya pola pembelajaran yang berpusat pada guru serta cara menyampaikan materi yang kurang menarik karena kurang melibatkan berbagai sumber media pembelajaran menyebabkan siswa menjadi cenderung cepat bosan dan pasif dalam pembelajaran. Rendahnya penggunaan media pembelajaran berbantuan komputer oleh guru bukan tanpa alasan. Menurut guru, perlu pengetahuan dan keterampilan yang memadai untuk membuat media yang layak untuk pembelajaran, selain itu media pembelajaran berbasis teknologi informasi juga masih sulit diperoleh serta tidak semua topik-topik yang memerlukan media berbasis teknologi informasi dan komunikasi sudah tersedia.

Siswa SMA yang berusia di atas 11 tahun berada pada tahap berpikir operasional formal (Piaget dalam Slavin, 2011), namun siswa SMA seringkali masih mengalami kesulitan dalam memahami materi-materi yang bersifat abstrak. Ovulasi dan fertilisasi di dalam organ reproduksi wanita sulit untuk dieksplorasi secara detil karena sifatnya abstrak. Pokok bahasan sistem reproduksi ini juga memiliki nilai pendidikan seks (Sex Education) yang tentu saja perlu arahan dari guru dalam proses pembelajaran sehingga tidak menimbulkan interpretasi negatif pada siswa. Kondisi demikian dapat menyebabkan kesulitan bagi siswa untuk menguasai dan memahami materi-materi proses gametogenesis, ovulasi, fertilisasi dan kehamilan yang sifatnya sulit dipahami tersebut sehingga menyebabkan terjadinya rendahnya pemahaman siswa terhadap materi itu.

Hasil analisa wawancara terhadap siswa yaitu materi sistem reproduksi yang sifatnya sulit dipahami seperti proses gametogenesis, ovulasi, fertilisasi, dan kehamilan karena proses tersebut tidak bisa dilihat secara langsung dari luar tubuh sehingga menjadi kurang kongkrit maka harus disampaikan dengan cara memvisualkan proses tersebut melalui video dan animasi sehingga mudah dipahami oleh siswa. Cara memvisualkan materi tersebut adalah dengan dengan bantuan media dalam hal ini media yang berbantuan komputer.

Proses penyampaian materi sistem reproduksi dengan multimedia interaktif melalui metode inkuiri, sehingga siswa dapat lebih memahami materi serta belajar mandiri maka akan terjadi proses pembelajaran yang berpusat pada siswa. Penggunaan media pembelajaran interaktif dengan metode inkuri ini akan melatih keterampilan berpikir kritis siswa. Multimedia interaktif yang memvisualkan konsep yang sulit akan memacu siswa untuk bertanya hal-hal yang relevan dan selanjutnya akan mencari jawaban dari pertanyaan itu melalui bantuan media sehingga tumbuh ketrampilan berpikir kritis siswa. Pembelajaran dengan bantuan multimedia bisa menjadi solusi, karena dengan metode 
ini memiliki banyak sekali keunggulan. Multimedia memiliki keunggulan diantaranya adalah keterlibatan organ tubuh seperti telinga (Audio), mata (visual), dan tangan (kinetik) keterlibatan berbagai organ ini membuat informasi yang disampaikan menjadi lebih mudah dimengerti (Arsyad, 2013).

Pengembangan multimedia yang digunakan dalam pembelajaran tentu saja harus mengacu pada tujuan dalam kurikulum sehingga akan menumbuhkan kemampuan berpikir kritis siswa sebagai kemampuan generik abad -21. Selain hal yang diungkapkan di atas, sebagai bahan acuan yang lain, telah dilakukan analisa dan studi awal terhadap berbagai produk multimedia yang dijual dipasaran, ternyata masih terdapat banyak celah yang dapat dikembangkan lebih lanjut sesuai dengan tuntutan pembelajaran.

Hasil analisis produk CD interaktif yang sudah ada dipasaran seperti anavisi edutama, bamboomedia, grafindo dan pustekom umumnya belum memuat model yang dimulai dari menampilkan fakta dan pertanyaan bagi siswa, visualisasi mekanisme pada sistem reproduksi yang ada belum maksimal menggambarkan proses tersebut, selain itu video yang tersedia pada situs youtube masih sulit dipahami oleh siswa jika tidak dibantu oleh guru. Beberapa hal ini juga menjadi salah satu alasan untuk mengembangkan multimedia interaktif yang diharapkan lebih baik dan juga sesuai dengan pola pembelajaran saat ini yaitu pembelajaran dengan pendekatan saintifik.

Keunggulan multimedia yang dikembangkan adalah: sudah mengacu pada kurikulum 2013, memuat peta konsep interaktif, pendahuluan berupa wacana yang disertai dengan pertanyaan-pertanyaan yang dapat membantu mengarahkan siswa untuk berpikir kritis , materi yang lebih dalam dan terstruktur dengan sumber mutakhir disertai bacaan tambahan serta tersedianya pertanyaan inkuiri pada setiap topik, adanya animasi dan visualisasi proses yang memerlukan waktu lama untuk pengamatan langsung yang dibantu dengan video , memuat video tentang tahapan perkembangan manusia, lembar kerja interaktif, latihan soal dengan penilaian, solusi dan umpan balik bagi siswa, menyediakan glosarium untuk kata-kata yang sulit, layout menu mudah diakses dari halaman manapun. Jika pada saat pembelajaran laptop dikoneksikan dengan internet maka siswa dapat membuka link yang bisa berhubungan dengan website sumber materi tanpa harus membuka mesin pencari.

Media pembelajaran interaktif yang murni tanpa dibantu dengan strategi pembelajaran yang tepat tentu tidak akan maksimal hasilnya karena hanya sekedar membuat siswa tertarik saja. Salah satu pendekatan pembelajaran yang dapat menumbuhkan keterampilan berpikir kritis siswa adalah pembelajaran inkuiri.
Menurut Mulyasa (2005) inkuri menempatkan peserta didik sebagai subyek belajar yang aktif. Kardi (2013) menyatakan bahwa inkuiri adalah proses untuk menjawab pertanyaan dan memecahkan masalah berdasarkan fakta dan observasi. Menurut Sutrisno (2012) Paradigma yang berkembang adalah teknologi dapat mendukung pembelajaran inkuiri, kolaborasi dan reposisi dalam melaksanakan proses pembelajaran. Sehingga strategi inkuiri yang dipadukan dengan media interaktif dan LKS akan mengembangkan kemampuan berpikir kritis siswa. Model ini adalah integrasi antara materi, pedagogi dan teknologi atau lebih dikenal dengan istilah technology, pedagogy content knowledge (TPACK) (Mishra et al dalam Sutrisno, 2012).

Pengembangan perangkat pembelajaran yang digunakan mengacu pada model Dick \& Carey. Desain pengembangan media mengacu pada model ASSURE yang diadaptasi dari Wiyono (2009). Pengembangan media akan dipadu dengan LKS yang memuat pertanyaan -pertanyaan untuk melatih kemampuan berpikir kritis siswa.

Sebagai landasan untuk memperkuat penelitian ini adalah hasil penelitian Ching \& Fook (2013) yang menyatakan nilai positif dari model multimedia grafis untuk meningkatkan dan memfasilitasi kemampuan berpikir kritis siswa serta hasil penelitian dari Milovanovic, dkk (2013) yang menyimpulkan ada hasil positif yang signifikan pembelajaran dengan menggunakan Multimedia Interaktif dibandingkan dengan menggunakan metode pembelajaran konvensional.

Hasil penelitian Fuad (2013) yang menyimpulkan bahwa pembelajaran dengan menggunakan animasi berbasis inkuri dapat meningkatkan keterampilan berpikir kritis siswa. Hasil penelitian lain yang menjadi rujukan adalah penelitian Wibowo (2013) dengan kesimpulan multimedia interaktif struktur dan fungsi jaringan tumbuhan dapat membantu meningkatkan kualitas pembelajaran biologi.

Dasar teori pembelajaran yang melandasi penggunaan multimedia ini adalah teori yang diungkapkan oleh Vygostky (Slavin, 2011) bahwa Pembelajaran melibatkan perolehan tanda-tanda melalui pengajaran dan informasi dari orang lain. Sehingga jika dikaitkan penggabungan media dan lembar kerja siswa sejalan dengan pendapat Vygostky ini. Siswa dapat belajar mandiri dan sedikit bantuan dari guru untuk memperoleh informasi tentang suatu hal. Selain itu Ausubel juga menyatakan bahwa pembelajaran bermakna sejalan dengan konstruksi pengetahuan dimana siswa membuat makna atas pengalamannya. Ini bermakna bahwa dengan bantuan multimedia siswa akan diberikan pengalaman yang nyata atas apa yang dipelajarinya. 


\section{METODE PENELITIAN}

Penelitian ini merupakan penelitian pengembangan karena mengembangkan perangkat pembelajaran biologi berupa Multimedia interaktif berbasis inkuiri untuk meningkatkan hasil belajar dan melatih keterampilan berpikir kritis siswa. Perangkat pembelajaran yang dikembangkan adalah Rencana Pelaksanaan Pembelajaran (RPP), Multimedia interaktif, Lembar Kerja Siswa (LKS), Lembar Penilaian Hasil Belajar, dan Penilaian Keterampilan Berpikir Kritis.

Dalam penelitian ini, rancangan perangkat pembelajaran menggunakan model yang dikemukakan oleh. Pengembangan perangkat pembelajaran yang digunakan mengacu pada model Dick \& Carey. Alasan yang kuat untuk memilih model ini karena setiap langkah dalam pembelajaran memiliki kaitan antara satu dan yang lainnya. Ada beberapa hal yang menjadi kelebihan dari model ini yaitu: (1) setiap langkah jelas, sehingga dapat diikuti, (2) teratur, efektif dan efisien dalam pelaksanaan, (3) merupakan model atau perencanaan pembelajaran yang terperinci, sehingga mudah diikuti, (4) adanya revisi pada analisis instruksional, dimana hal tersebut merupakan hal yang sangat baik, karena apabila terjadi kesalahan maka segera dapat dilakukan perubahan pada analisis instruksional tersebut, sebelum kesalahan di dalamnya ikut mempengaruhi kesalahan pada komponen setelahnya, (5) model Dick \& Carey sangat lengkap komponennya, hampir mencakup semua yang dibutuhkan dalam suatu perencanaan pembelajaran. Desain pengembangan media mengacu pada model ASSURE yang diadaptasi dari Wiyono (2009).Tahapan pengembangan perangkat pembelajaran dapat dilihat pada Gambar 1.

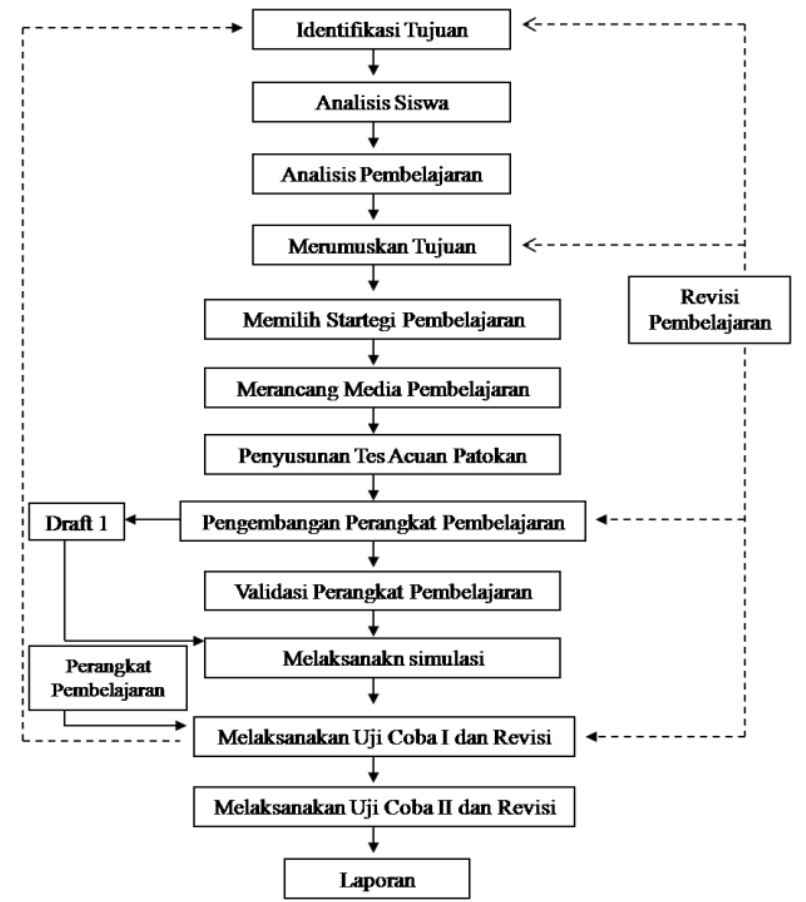

Gambar 1. Diagram Alir dari Tahapan Pengembangan Perangkat Pembelajaran

Tahap pengembangan multimedia interaktif dapat dilihat pada gambar 2 berikut :

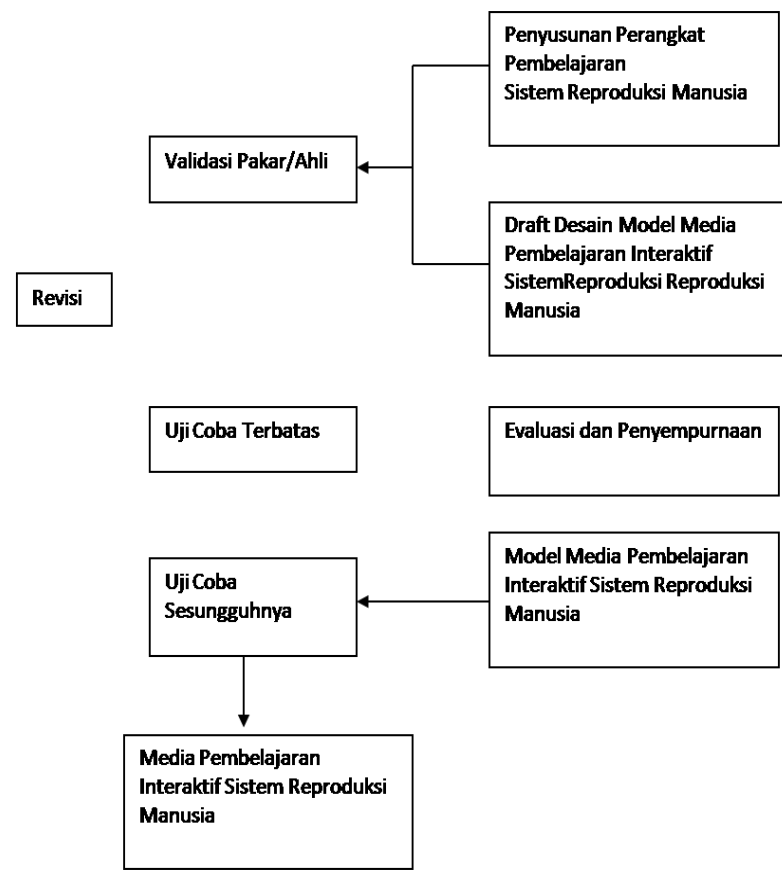

Gambar 2. Diagram pengembangan media (adaptasi dari wiyono 2009)

Dalam penelitian ini, perangkat akan melalui uji 1 pada sampel kecil dan uji 2 pada sampel besar. Desain uji coba perangkat menggunakan rancangan eksperimen Pre and Post Design :

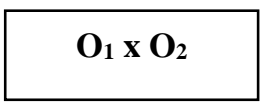

Teknik pengumpulan data yang digunakan dalam penelitian ini melalui observasi, pemberian tes, dan penyebaran angket.

Analisis data hasil pengembangan perangkat dan multimedia interaktif berbasis inkuiri dalam penelitian ini menggunakan analisis deskriftif adalah sebagai berikut.

1. Analisis Kualitas Perangkat Pembelajaran

Perangkat pembelajaran (RPP, Multimedia Interaktif, LKS dan Tes Hasil Belajar) ditelaah oleh validator untuk memberikan penilaian terhadap kelayakan penggunaannya. RPP, Multimedia Interaktif dan LKS ditelaah dengan Instrumen yang telah dikembangkan. Untuk Lembar Penilaian Hasil Belajar yang dikembangkan dilakukan validasi isi, bahasa dan penulisan soal sesuai dengan Instrumen. Data hasil validasi dianalisis secara deskriptif kualitatif. Dalam penelitian ini validitas perangkat dari hasil penilaian para validator dan kemudian dicocokkan dengan kriteria penilaian perangkat hasil pembelajaran. Adapun kriteria 
penilaian perangkat hasil pembelajaran dapat dilihat pada Tabel 1 berikut.

Tabel 1. Kriteria Pengkategorian Penilaian RPP, Multimedia Interaktif, LKS dan THB

\begin{tabular}{|c|c|}
\hline Rentang Skor & Kategori \\
\hline$\overline{\mathrm{X}}>3,50$ & Sangat Layak \\
\hline $3,00<\overline{\mathrm{X}} \leq 3,49$ & Layak \\
\hline $2,00<\overline{\mathrm{X}} \leq 2,99$ & Sedang \\
\hline $1,00<\overline{\mathrm{X}} \leq 1,99$ & Kurang \\
\hline$\overline{\mathrm{X}} \leq 1,00$ & Rendah \\
\hline
\end{tabular}

2. Analisis Tingkat Keterbacaan Multimedia Interaktif dan tanggapan siswa terhadap multimedia interaktif

Tingkat keterbacaan merupakan ukuran menarik atau tidaknya isi dan penampilan serta pemahaman siswa terhadap multimedia interaktif. Teknik analisis dilakukan secara deskriptif kuantitatif persentase. Siswa diminta memberikan pendapatnya mengenai keterbacaan media yang meliputi aspek layout/tampilan, isi, penjelasan materi dan kualitas ilustrasi

\section{Analisis Keterlaksanaan RPP}

Pengamatan keterlaksanaan RPP dilakukan oleh dua pengamat yang sudah dilatih memberikan penilaian yang tepat pada Instrumen. Data kemudian dianalisis secara deskriptif kuantitatif dengan menggunakan rumus:

$$
P=\frac{\sum K}{\sum N} \times 100 \%
$$

Keterangan:

$\mathrm{P}=$ Persentase keterlaksanaan RPP

$\sum K=$ Jumlah aspek yang terlaksana

$\sum N=$ Jumlah keseluruhan aspek yang diamati

Penilaian keterlaksanaan RPP pada setiap langkah ditentukan dengan membandingkan rata-rata skala penilaian yang diberikan kedua pengamat dengan kriteria penilaian sebagai berikut.

Tabel 3. Kriteria Penilaian Keterlaksanaan RPP Pada Setiap Langkah

\begin{tabular}{|c|c|c|}
\hline No & $\begin{array}{c}\text { Rerata Penilaian } \\
\text { Keterlaksanaan }\end{array}$ & Kategori \\
\hline 1 & $1,00-1,99$ & Tidak baik \\
\hline 2 & $2,00-2,99$ & Kurang baik \\
\hline 3 & $3,00-3,49$ & Cukup Baik \\
\hline 4 & $3,50-4,00$ & Baik \\
\hline
\end{tabular}

(Diadaptasi dari Kardi, 2002)

Selanjutnya dikonversikan dalam bentuk rubrik sebagai berikut :

1 = Tidak dilakukan sama sekali (tidak baik)

2 = Dilakukan tapi tidak selesai (kurang baik)

3 = Dilakukan tapi kurang tepat (cukup baik)

4 = Dilakukan, tepat dan sistematis (baik)
4. Analisis Aktivitas Siswa

Aktivitas siswa diukur oleh dua pengamat selama KBM berlangsung dengan menggunakan Instrumen. Data yang diperoleh selanjutnya dianalisis statistik deskriptif

$\%=$ aktivitas siswa

$$
=\frac{\text { Banyaknya frekuensi tiap aktivitas }}{\text { Seluruh aktivitas }} \times 100 \%
$$

\section{Analisis Hasil Belajar Siswa}

Berdasarkan data hasil posttest dianalisis secara deskriptif kualitatif tentang hasil belajar siswa yang meliputi hasil belajar sikap, pengetahuan, dan keterampilan.

a. Hasil Belajar Pengetahuan dan Keterampilan

Berdasarkan hasil posttest, hasil belajar pengetahuan dan keterampilan ditentukan ketuntasannya yaitu ketuntasan individual dan klasikal. Secara individual siswa dikatakan tuntas apabila ratarata ketercapaian indikator yang diwakili tujuan pembelajaran memenuhi Kriteria Ketuntasan Minimum (KKM) mata pelajaran fisika di SMA Negeri 1Batu Sopang yaitu 72 dengan perhitungan sebagai berikut: Ketuntasan Individual

$$
=\frac{\sum \text { Indikator yang Tuntas }}{\sum \text { Jumlah indikator dalam KD }} \times 100 \%
$$

Ketuntasan hasil belajar secara klasikal dihitung dengan menggunakan rumus:

Ketuntasan Klasikal $=\frac{\sum \text { Siswa yang Tuntas }}{\sum \text { Siswa }} \times 100 \%$

Pembelajaran secara klasikal dikatakan tuntas apabila $\geq$ $75 \%$ individu tuntas.

\section{b. Hasil Belajar Sikap}

Nilai yang diberikan oleh dua orang pengamat ditentukan rata-rata, kemudian hasil yang diperoleh dicocokan dengan kriteria penilaian sikap yang tercantum dalam permendiknas no81A tahun 2014. Ketuntasan individual siswa dikatakan tuntas jika memperoleh nilai setidaknya menunjukkan sedang. Ketuntasan klasikal tercapai jika $75 \%$ siswa tuntas.

\section{c. Normalized Gain}

Analisis data hasil belajar siswa pada saat pretes dan postest dihitung dengan menggunakan normalized gain sebagai berikut :

$$
<g>=\frac{\text { \%post test }-\% \text { pre test }}{100-\% \text { pre test }}
$$

Kategori normalized gain $\langle g\rangle$ :

Tinggi $:(\langle g\rangle) \geq 0.7$

Sedang : $0.7>(\langle g\rangle)>0.3$

Rendah : $(\langle g\rangle) \leq 0.3$

(Hake, 1999) 


\section{d. Sensitivitas Soal}

Indeks sensitivitas dari butir soal merupakan ukuran seberapa baik soal membedakan antara siswa yang telah menerima pembelajaran dengan siswa yang belum menerima pembelajaran. Indeks sensitivitas mempunyai rentang antara 0 sampai 1 . Untuk menghitung sensitivitas soal digunakan rumus sebagai berikut.

$$
S=\frac{B s s-B s b}{T}
$$

(Kardi, 2002)

Keterangan:

Bss = Banyaknya siswa yang menjawab benar pada tes akhir

$\mathrm{Bsb}=$ Banyaknya siswa yang menjawab benar pada tes awal

$\mathrm{T}=$ Banyaknya siswa yang mengikuti tes

Indeks sensitivitas antara 0.00 sampai 1.00 ,butir soal dikatakan peka terhadap efek-efek pembelajaran apabila sensitivitas soal lebih besar atau sama dengan 0,40. (Gronlund, 1977).

\section{Analisis Keterampilan Berpikis Kritis}

Berdasarkan data hasil tes berpikir kritis dilakukan analisis secara deskriptif kualitatif dari perolehan skor siswa. Analisis keterampilan berpikir kritis siswa dilakukan dengan memberikan skor siswa dalam menjawab soal tes berbentuk pilihan ganda dan essay. Pemberian skor berdasarkan skala berpikir kritis menurut Ennis, yaitu tidak terampil (1), kurang terampil (2), terampil (3) dan sangat terampil (4). Hasil belajar keterampilan berpikir kritis siswa pada saat pretes dan postest dianalisis dengan menggunakan normalized gain untuk melihat perkembangan keterampilan berpikir kritis siswa.

\section{Minat Siswa}

Minat Siswa diperoleh dengan menggunakan angket ARCS dari keller (1987). Selanjutnya hasil dari angket tersebut ditafsirkan dengan kategori respon minat.

\section{Analis Kendala Selama Pembelajaran}

Temuan kendala-kendala selama proses pembelajaran dianalisis secara deskriptif kualitatif melalui diskusi antara pengamat dan peneliti. Diskusi diperlukan untuk mencari solusi atas kendala yang ditemukan.

\section{HASIL PENELITIAN DAN DISKUSI}

Berdasarkan hasil validasi dari para validator terhadap perangkat dan multimedia interaktif yang dikembangkan maka diperoleh hasil seperti pada Tabel berikut ini :
Tabel 4. Hasil analisis Instrumen

\begin{tabular}{|l|c|c|c|c|}
\hline $\begin{array}{l}\text { Instru } \\
\text { men }\end{array}$ & $\begin{array}{l}\text { Skor } \\
\text { rata-rata }\end{array}$ & Validitas & Reliabilitas & Kategori \\
\hline RPP & 3,60 & Valid & $98 \%$ & Reliabel \\
\hline Media & 3,70 & Valid & $97 \%$ & Reliabel \\
\hline LKS & 3,68 & Valid & $98 \%$ & Reliabel \\
\hline THB & 3,56 & Valid & $97,2 \%$ & Reliabel \\
\hline
\end{tabular}

Hasil penilaian para ahli ini menunjukkan bahwa perangkat berupa RPP, Multimedia Interaktif, LKS, dan THB telah valid dan reliabel sehingga layak untuk digunakan dalam proses pembelajaran.

Tabel 5. Hasil implementasi pada proses pembelajaran

\begin{tabular}{|l|l|l|}
\hline \multicolumn{1}{|c|}{ Item } & Skor rata-rata & \multicolumn{1}{|c|}{ Keterangan } \\
\hline RPP & $3,56 \%$ & $\begin{array}{l}\text { Terlaksana } \\
\text { dengan baik }\end{array}$ \\
\hline $\begin{array}{l}\text { Aktivitas } \\
\text { siswa }\end{array}$ & $86,6 \%$ & $\begin{array}{l}\text { Relevan dengan } \\
\text { KBM }\end{array}$ \\
\hline $\begin{array}{l}\text { Penilaian } \\
\text { Media }\end{array}$ & $9,84 \%$ & $\begin{array}{l}\text { Menarik, mudah } \\
\text { dipahami }\end{array}$ \\
\hline Hasil belajar & $100 \%$ & Tuntas \\
\hline
\end{tabular}

Multimedia interaktif berbasis inkuiri yang dihasilkan memiliki keunggulan membantu siswa untuk berpikir kritis karena media disajikan dengan gambar dan pertanyaan-pertanyaan yang memerlukan tahapan berpikir, dilengkapi dengan pertanyaan-pertanyaan berpikir kritis, terdapat simulasi praktikum ,media ini juga dilengkapi dengan lembar kerja siswa ,seperti pada tampilan berikut :

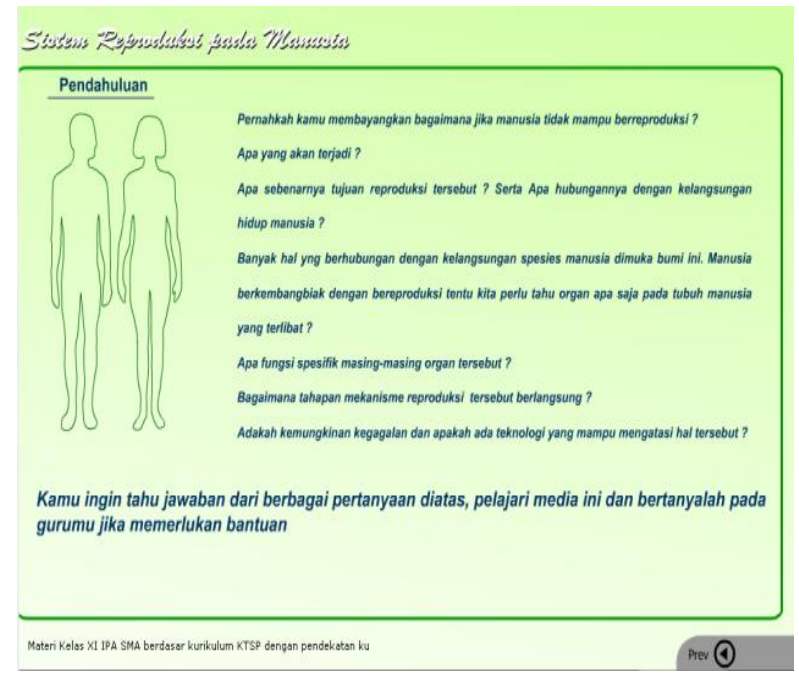

Gambar 3. Tambilan simulasi media

Setiap halaman materi menyediakan bacaan tambahan yang dapat membantu siswa memahami materi, sehingga pada saat siswa mengalami kesulitan untuk maka dapat mencari sumber dari bacaan tambahan yang tersedia dengan mengklik ikon bergambar buku yang tersedia. 


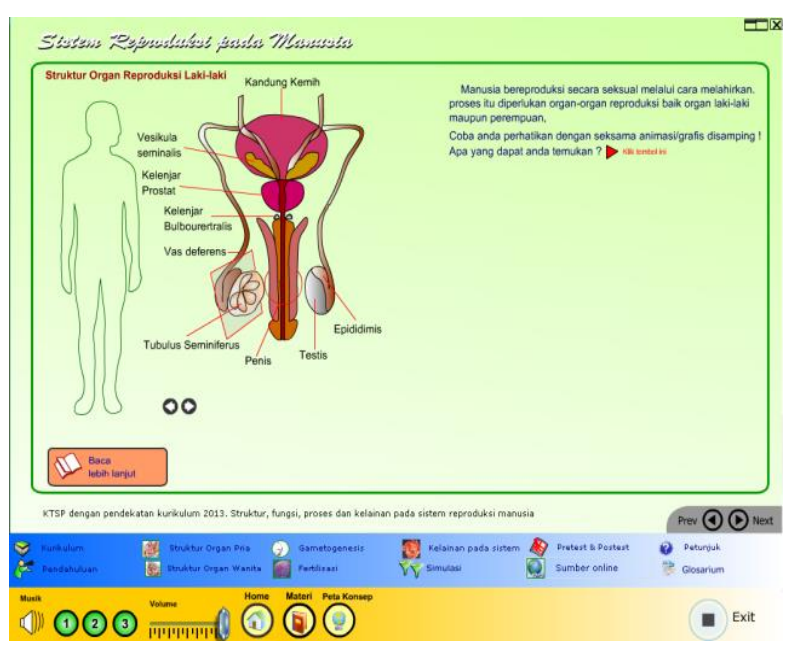

Gambar 4. Tampilan simulasi organ kelamin laki-laki

Halaman simulasi yang tersedia dapat membantu siswa memahami pengetahuan yang memerlukan proses yang lama dan sulit, seperti simulasi uji kehamilan, fertilisasi invitro dan simulasi mikroskop pada gambar di bawah ini :

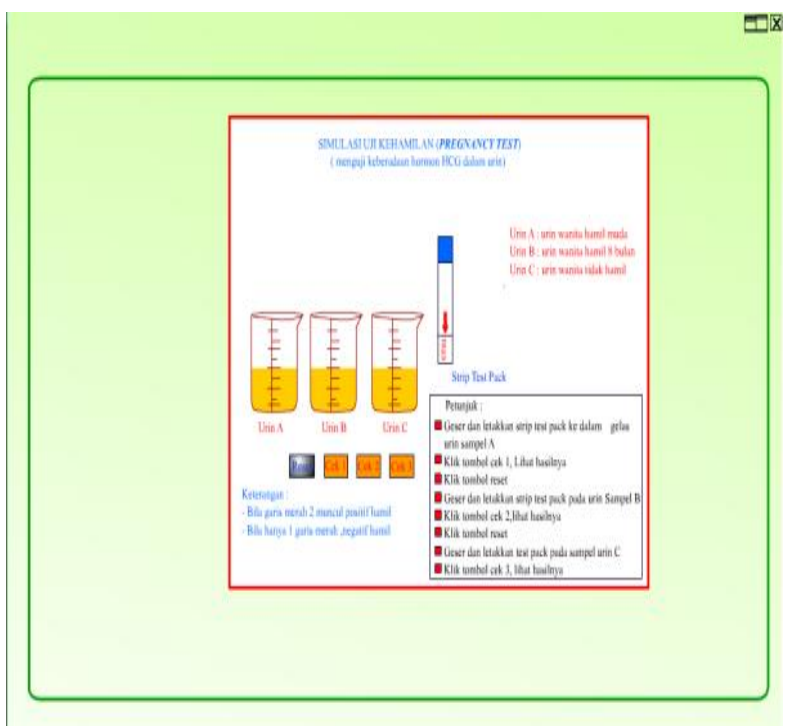

Gambar 5. Simulasi uji kehamilan

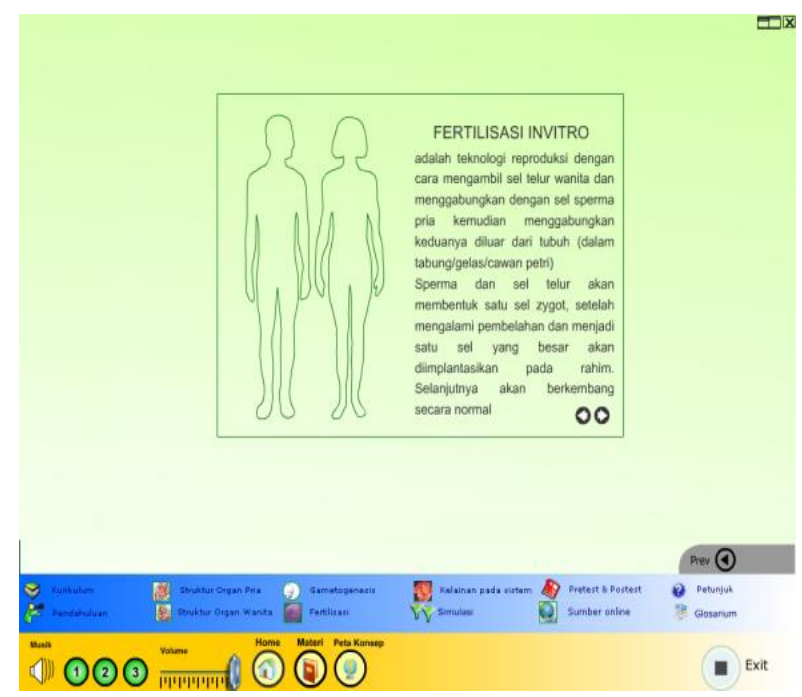

Gambar 6. simulasi fertilisasi invitro

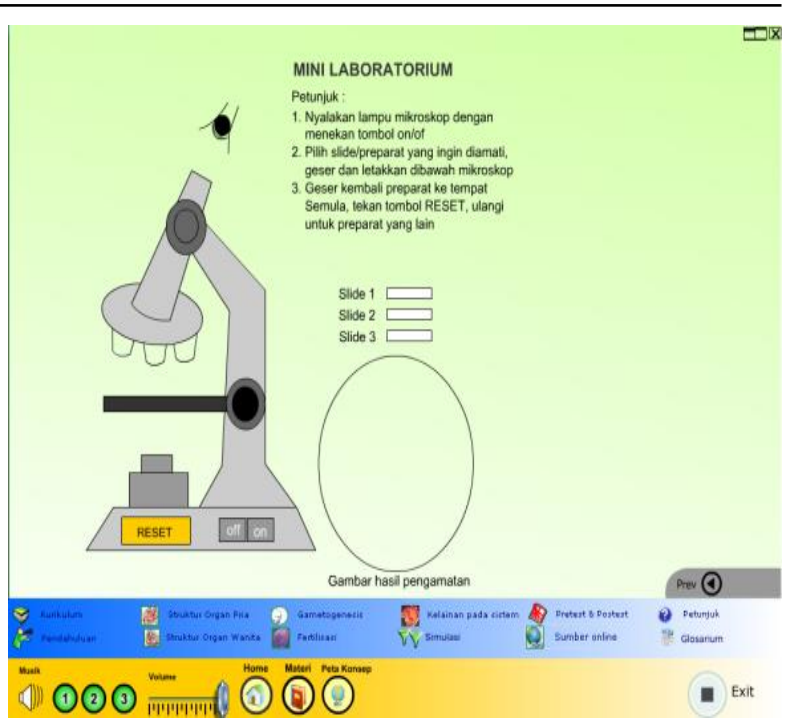

Gambar 7. Simulasi mikroskop

Selain itu juga tersedia lembar kerja interaktif yang dapat digunakan oleh siswa untuk menguji pemahaman materi :

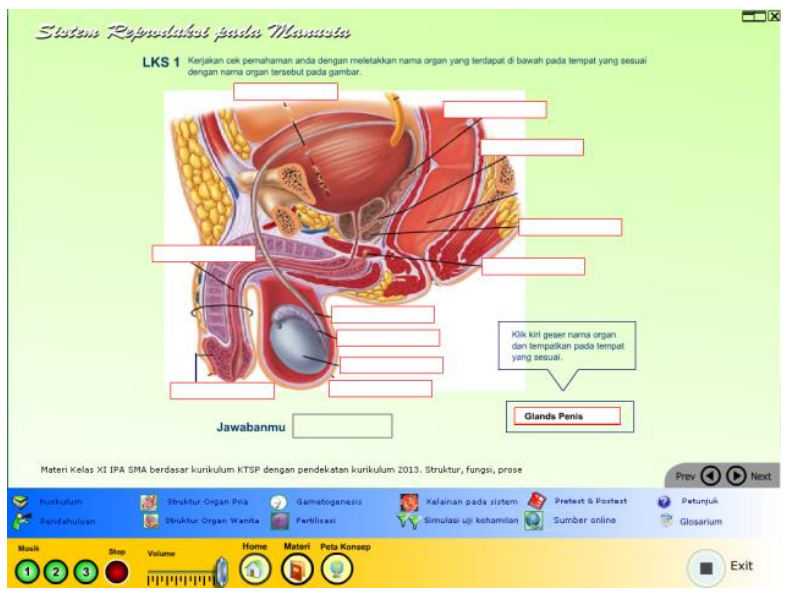

Gambar 7. LKS dalam bentuk media

Multimedia interaktif berbasis inkuri selanjutnya digunakan dalam proses pembelajaran untuk mengetahui peningkatan hasil belajar dan melatih keterampilan berpikir kritis siswa.

\section{A. Keterlaksanaan Kegiatan Pembelajaran (RPP)}

Keterlaksanaan RPP adalah hasil pengamatan yang dilakukan oleh dua orang pengamat menggunakan instrumen pengamatan keterlaksanaan RPP yang dilakukan oleh peneliti (guru). Pengamat melakukan penilaian atas keterlaksanaan komponen-komponen pembelajaran yang dirancang dalam RPP.

Berdasarkan hasil analisis pengamatan keterlaksanaan diperoleh nilai rata-rata untuk semua aspek 3,92 . Skor rata-rata ini mempunyai makna bahwa kegiatan pembelajaran sudah dilaksanakan dengan baik oleh guru meskipun masih ada kekurangannya dalam pengelolaan waktu, hasil ini mengacu pada kriteria keterlaksanaan yang dikemukakan oleh Arikunto (2010) 
bahwa skor maksimum yang harus diperoleh guru untuk kategori sempurna adalah 5,00.

Hasil analisis keterlaksanaan perangkat dalam proses pembelajaran ini berarti bahwa perangkat pembelajaran yang dgunakan sudah memperhatikan karakteristik siswa, tujuan pembelajaran, pemilihan bahan ajar serta pengadaan media yang digunakan (Munadi, 2008)

Implementasi RPP pada pertemuan I, II, III dan IV sudah terlaksana dengan baik, hal ini menunjukkan bahwa pembelajaran menggunakan multimedia interaktif yang menggunakan strategi inkuiri secara keseluruhan sudah diimplementasikan dalam proses pembelajaran.

Pada tahap pendahuluan terdapat fase mengajukan pertanyaan yang diperoleh dari tayangan beberapa fakta pada media pembelajaran dan dibantu oleh beberapa pertanyaan. Apersepsi ini berupa video yang kemudian diikuti dengan pertanyaan kepada siswa sehingga akan menimbulkan minat siswa untuk mengetahui lebih dalam mengenai materi yang sedang dipelajari, sehingga pada fase ini akan terjadi proses mengamati kemudian menanya. Hal ini sesuai dengan pendapat Naim (2009) siswa akan lebih tertarik pada pembelajaran yang sifatnya auditif dan visualitatif. Pendapat ini juga diperkuat oleh Levie dan Levie (dalam Arsyad, 2013) bahwa stimulus visual dalam hal ini video yang ditayangkan diawal pembelajaran membuahkan hasil belajar yang lebih baik untuk mengingat, mengenali, mengingat kembali serta menghubungkan fakta dengan konsep.

Pada kegiatan inti siswa akan diarahkan menggunakan media untuk memperoleh informasi berupa data dan fakta mengenai pertanyaan yang sudah diajukan, selanjutnya untuk lebih membantu siswa menemukan jawaban maka siswa juga mengerjakan lembar kerja interaktif pada media serta lembar kerja siswa yang berupa kertas kerja. Langkah terakhir yang dilakukan siswa adalah mengkonfirmasikan hasil pencariannya dengan melakukan presentasi dan mengajukan argumen serta kesimpulannya. Keberadaan media yang mengedepankan stimulus siswa untuk bertanya ini sesuai dengan pendapat Thorndike (dalm Sagala, 2006) tentang teori belajar behavioristik yang mengatakan bahwa stimulus dapat merangsang terjadinya kegiatan belajar.

Langkah-langkah pembelajaran menggunakan multimedia interaktif yang dipadu dengan strategi inkuiri dimana guru hanya menyediakan panduan berupa pertanyaan-pertanyaan selanjutnya siswa sendiri yang menemukan jawabannya. Hal ini sesuai dengan pendapat Ristanto (2010) bahwa inkuiri terbimbing adalah guru hanya berperan memberikan pertanyaanpertanyaan dalam proses penemuan.
Fase pembelajaran inkuiri menurut Eggen dan Kaucak (2013) adalah : menyajikan pertanyaan, membuat hipotesis, merancang percobaan, melakukan percobaan untuk memperoleh informasi, mengumpulkan dan menganalisis data, serta menarik kesimpulan. Sementara jika dipadu dengan multimedia interaktif maka fase pembelajaran inkuiri menurut Setiawan (2013): penyajian masalah melalui media, pengumpulan data memanfaatkan media, eksplorasi dan simulasi virtual dengan media, membuat jawaban dari hipotesis, membuat kesimpulan.

Berdasarkan hasil pengamatan pelaksanaan pembelajaran yang dilakukan oleh guru (peneliti) maka dapat diambil suatu kesimpulan bahwa perangkat pembelajaran (RPP) yang dikembangkan dapat terlaksana dengan baik dengan perbaikan pada pengelolaan alokasi waktu. Ketepatan alokasi waktu berkaitan dengan model pembelajaran yang digunakan yaitu menggunakan media interaktif berbasis inkuiri yang membuat siswa sangat antusias dan tertarik dengan media yang digunakan sehingga menyebabkan waktu yang digunakan menjadi tidak sesuai, siswa antusias bertanya tentang visualisai materi pada media dan proses tanya jawab menggunakan waktu yang lebih banyak.

\section{B. Keterbacaan Media Pembelajaran}

Media pembelajaran sebelum digunakan secara luas harus dievaluasi terlebih dahulu, baik dari segi materi, segi edukatif maupun dari segi rekayasa perangkat lunaknya, sehingga media pelajaran memenuhi syarat untuk digunakan dalam proses pembelajaran. Evaluasi yang dimaksud untuk mengetahui apakah media yang dikembangkan dapat mencapai tujuan yang ditetapkan. Hal ini menjadi sangat penting karena banyak orang beranggapan bahwa sekali membuat media pasti baik. Proses pengujian diawal telah dilakukan dengan mengkonsultasikan pada ahli atau pakar melalui proses validasi. Setelah proses ini selesai dan dinyatakan layak seperti yang diperlihatkan pada tabel 4.4 tentang validasi media oleh ahli, maka langkah selanjutnya adalah evaluasi formatif satu lawan satu (one to one) dan evaluasi kelompok kecil (small group evaluation). Pada tahap ini media diujicobakan pada kelompok kecil dengan jumlah sampel 12 siswa dengan kategori tingkat pemahaman rendah, sedang dan tinggi dan keberagaman jenis kelamin. Penilaian yang dilakukan adalah tingkat keterbacaan media pembelajaran interaktif. Selanjutnya media diimplementasikan pada skala yang lebih luas dengan jumlah sampel 30 orang.

Berdasarkan hasil penilaian keterbacaan media pembelajaran oleh siswa diperoleh data seperti yang tertera pada tabel 4.8 yang meliputi empat aspek 
penilaian diperoleh hasil bahwa $100 \%$ siswa menyatakan isi media pembelajaran menarik, $100 \%$ menyatakan penampilan media menarik , $0 \%$ menyatakan tidak menarik, $0 \%$ siswa menyatakan penjelasan materi dalam media sulit, $13 \%$ menyatakan tidak ada kesulitan, $87 \%$ menyatakan cukup dan $100 \%$ siswa menyatakan ilustrasi, gambar dan animasi dalam media pembelajaran dapat membantu pemahaman.

Nilai rata-rata tingkat keterbacaan media oleh siswa terhadap empat aspek penilaian adalah $91,66 \%$, nilai ini dikategorikan mudah, artinya siswa atau pengguna mudah untuk mengerti isi materi yang disampaikan serta sangat terbantu pemahaman dengan kualitas ilustrasi, gambar dan animasi yang tersedia. Penilaian keterbacaan media ini didasarkan pada pendapat Heaton (dalam Sitepu, 2010) menyatakan bahwa apabila nilai keterbacaan $\geq 50 \%$ maka dinyatakan bahwa pengguna atau pembaca mudah mengerti isi dari bacaan tersebut.

\section{Tanggapan siswa terhadap Media Pembelajaran.}

Selain tingkat keterbacaan media, evaluasi juga dilakukan oleh siswa terhadap aspek kemudahan pemahaman, kemandirian belajar, penyajian media dan pengoperasian media. Berdasarkan analisis pada grafik 4.8 diperoleh hasil tanggapan siswa 54\% sangat setuju, $39 \%$ setuju, 6,5\% ragu-ragu, $0,5 \%$ tidak setuju dan $0,5 \%$ kurang setuju. Jika dinilai secara rata-rata maka media pembelajaran ini mendapat tanggapan positif dari siswa ini berarti bahwa media pembelajaran layak untuk digunakakan. Kelayakan tanggapan siswa ini sesuai dengan pendapat Wahono (2006) tentang peniaian media pembelajaran yang harus memenuhi aspek rekayasa perangkat lunak yang meliputi efektif dan efisien, handal, dapat dikelola dengan mudah, sederhana dalam pengoperasian, tepat dalam memilih software pengembang, pemaketan program sudah terpadu sehingga mudah dalam eksekusi, dokumentasi program media pembelajaran lengkap (petunjuk instalasi, trouble shooting serta desain program), reusable (sebagian atau seluruh program media pembelajaran dapat dimanfaatkan kembali untuk mengembangkan media pembelajaran lain)

\section{Aktivitas Siswa}

Berdasarkan hasil analisis aktivitas siswa diperoleh hasil skor rata-rata 86,6\% untuk semua aspek aktivitas yang diamati. Aspek yang memiliki skor terendah adalah pengamatan terhadap siswa yang pasif atau menjadi pendengar saja. Hasil ini merepresentasikan bahwa siswa aktif dalam proses pembelajaran dan terjadi pemerataan pada setiap aktivitas siswa, tidak ada aktivitas yang dominan, fakta penelitian ini juga menunjukkan bahwa penggunaan media interaktif tidak menjadi pengganggu dalam proses pembelajaran tetapi menjadi satu aspek yang menunjang proses pembelajaran karena ada kesinambungan antara penggunaan media dengan proses pembelajaran yang lain.

Hal ini disebabkan oleh penggunaan media juga dipadu dengan LKS yang merupakan satu kesatuan dengan media pembelajaran. Proses pembelajaran berjalan sebagaimana yang dirancang dalam RPP, siswa aktif mengeksplorasi pengetahuan melalui media dibantu dengan pemahaman lanjut melalui LKS dan guru sebagai fasilitator. Sehingga jika dikaitkan penggabungan media dan lembar kerja siswa sejalan dengan pendapat Vygostky (Slavin, 2011). Siswa dapat belajar mandiri dan sedikit bantuan dari guru untuk memperoleh informasi tentang suatu hal.

Aspek yang memperoleh skor tertinggi adalah aspek mendengarkan penjelasan guru, mencari informasi melalui media, mengoperasikan media dan mengerjakan lembar kerja siswa. Hal ini sesuai dengan teori Piaget (Nur, 2004) bahwa anak memiliki rasa ingin tahu yang akan terus berusaha untuk memahami apa yang ada disekelilingnya. Sejalan dengan itu Meyer (2009) juga mengungkapkan teori kognitif yang dikandung dalam media pembelajaran yaitu menyeleksi kata-kata dan gambar yang relevan, mengorganisasi kata-kata, mengorganisasi gambar dan menghubungkan antara gambar dengan kata-kata untuk memperoleh suatu informasi pengetahuan yang utuh. Pendapat Piaget dan Meyer ini juga diperkuat oleh teori penemuan dari Bruner (dalam Arsyad, 2013) yang mengatakan ada tiga tingkatan utama modus belajar, seseorang belajar melalui pengalaman langsung (enactive), pengalaman piktorial/gambar (iconic), dan pengalaman abstrak (symbolic), teori ini menyatakan bahwa siswa akan belajar dengan cara mencocokkan antara kata dan gambar yang dapat dilihat secara visual. Tingkat pengalaman belajar seperti ini juga tertuang dalam kerucut pengalaman Dale (dalam Fadel, 2008) yang dikenal sebagai suatu proses komunikasi.

\section{E. Efektivitas Penggunaan Media}

Efektifitas penggunaan media interaktif dalam proses pembelajaran dapat diketahui dengan cara melihat ketuntasan belajar siswa yang diukur pada tiga aspek yaitu kognitif, keterampilan dan afektif. Selain itu tingkat sensitifitas butir soal juga diukur untuk memperoleh kesimpulan pengaruh proses pembelajaran terhadap peningkatan kemampuan siswa. Nilai peningkatan kemampuan siswa diukur dengan menggunakan rumus Hake (1999).

1. Hasil belajar Kognitif (pengetahuan)

Hasil belajar siswa meliputi ranah kognitif, psikomotor dan afektif. Hasil belajar kognitif yang 
diukur berupa ketuntasan indikator, ketuntasan individual dan ketuntasan klasikal serta nilai sensitivitas instrumen butir soal. Hasil belajar kognitif ditunjukkan oleh siswa melalui perolehan nilai setelah menjawab soal tes kemampuan kognitif dengan proporsi $60 \%$ untuk soal pilihan ganda dan $40 \%$ untuk soal uraian.

a. Ketuntasan Indikator

Tes hasil belajar dilakukan untuk mengetahui sejauh mana siswa dapat mencapai tujuan pembelajaran yang ditentukan. Tes dilakukan dua kali yaitu pada awal pembelajaran dan pada akhir pembelajaran. Hasil tes pada akhir pembelajaran merupakan indikator ketuntasan dari proses pembelajaran. Berdasarkan data yang diperoleh dilihat bahwa seluruh indikator pembelajaran berhasil tuntas dengan persentase $83 \%$ sampai $100 \%$. Hasil ini merepresentasikan bahwa model pembelajaran yang dipilih serta media yang digunakan mempunyai peran yang penting dan efektif dalam proses pembelajaran. Ketuntasan belajar ini juga tidak lepas dari peran guru sebagai fasilitator yang membantu siswa dalam belajar jika siswa mengalami kesulitan. Proses belajar yang aktif juga berperan hal ini mengacu pada hasil analisis aktivitas siswa yang menyatakan siswa aktif dalam belajar.

b. Ketuntasan Individual

Ketuntasan individual adalah ketuntasan yang diperoleh oleh siswa untuk setiap indikator pada butir soal yang diujikan. Berdasarkan hasil analisis terjadi peningkatan penguasaan konsep tentang materi pelajaran ini dilihat dari peningkatan skor terendah pre test 15,2 meningkat menjadi tertinggi pada post test 96,8 . Pada pre test, hasil belajar siswa belum tuntas dengan skor terendah 15,2 ini dikarenakan siswa belum mempelajari materi tersebut serta belum ada perlakuan belajar terhadap siswa, hanya kemampuan awal siswa saja yang dilihat pada tahap ini. Setelah dilakukan perlakuan berupa pembelajaran dengan menggunakan media interaktif berbasis inkuri disertai LKS, maka pada post tes diperoleh hasil peningkatan semua siswa tuntas.

Siswa juga mengalami peningkatan penguasaan materi dengan skor $\mathrm{N}$ (gain) $0,5-1,0$, hal ini menunjukkan efektifitas pembelajaran untuk meningkat keterampilan pemahaman siswa sesuai dengan pendapat Hake (1999) yang menyatakan nilai $\mathrm{N}$ (gain) > 0,7 dikelompokkan sebagai peningkatan yang tinggi. Peningkatn hasil belajar ini menunjukkan bahwa perangkat dan media interaktif dipadu strategi inkuiri yang digunakan dalam pembelajaran mempunyai tingkat efektivitas yang tinggi untuk meningkatkan hasil belajar siswa. Hasil ini sesuai dengan hasil penelitian Wiyono (2009) yang menyimpulkan bahwa model pembelajaran multimedia interaktif dapat mempermudah mempelajari konsep-konsep yang bersifat abstrak dan mikroskopis serta dapat mengadaptasi gaya belajar yang berbeda. Keterampilan berpikir kritis siswa juga mengalami peningkatan ini membuktikan bahwa pembelajaran multimedia yang dipadukan dengan model inkuiri akan menumbuhkan kemampuan berpikir kritis siswa, karena proses pembelajaran dengan menggunakan media ini diawali dengan kegiatan menemukan pertanyaan dari gambar atau fakta yang disajikan.

Keberhasilan siswa dalam belajar ini sesuai dengan pendapat Hamalik (2003), bahwa ada lima unsur yang terkait dalam proses belajar yaitu: motivasi belajar, bahan belajar, alat bantu belajar (media), suasana belajar dan kondisi subyek belajar, sehingga media mempunyai potensi yang sangat besar dalam membantu keberhasilan proses belajar. Wicaksono (2012 ) juga menyimpulkan model media pembelajaran interaktif visual meningkatkan aktivitas belajar dan hasil belajar siswa.

Ketuntasan belajar yang diperoleh siswa pada penelitian ini tentu memperkuat hasil penelitian Chiing (2013) yang mengemukan bahwa model pembelajaran multimedia memberi nilai positif dan dapat memfasilitasi siswa untuk meningkatkan keterampilan berpikir kritis. Hasil penelitian lain yang mendukung adalah penelitian Sutarno (2011) yang menyimpulkan bahwa mahasiswa yang mengikuti pembelajaran menggunakan multimedia interaktif secara siginifikan lebih tinggi hasil belajarnya daripada yang mengikuti pembelajaran konvensional.

Ali (2009) juga mengatakan bahwa pembelajaran dengan multimedia interaktif sangat membantu mahasiswa memahami materi, meningkatkan semangat belajar dan kompetensi. Indrawan (2013) juga mengatakan ada perbedaan hasil yang signifikan antara nilai rata-rata hasil belajar peserta didik sebelum dan sesudah menggunakan perangkat pembelajaran multimedia interaktif. Hasil penelitian Wahyudin (2010) menyimpulkan bahwa penerapan metode pembelajaran inkuri terbimbing dengan bantuan multimedia dapat meningkatkan minat dan pemahaman siswa. Widayat ( 2014) juga menyimpulkan bahwa multimedia intraktif dapat meningkatkan hasil belajar $100 \%$ secara klasikal.

Hasil penelitian diatas tentu sejalan dengan teori belajar behavioristik dari Thorndike (Sagala, 2006) yang memandang bahwa belajar sebagai kegiatan yang bersifat meknistik antara stimulus dan respon,merujuk pada teori ini maka dapat dikatakan bahwa belajar dengan multimedia interaktif merupakan stimulus dari 
media selanjutnya mendapat respon dari siswa sehingga tercipta pemrosesan informasi.

Letak hubungan antara multimedia interaktif yang dipadu dengan model pembelajaran inkuiri dengan hasil belajar adalah media tersebut merupakan alat yang secara fisik digunakan untuk menyampaikan materi pengajaran (Gagne dan Brigs dalam Arsyad, 2013). Cara komunikasi menyampaikan informasi pengetahuan dalam proses pembelajaran yang memadukan unsur verbal dan visual tentu akan lebih memudahkan siswa memahami materi pelajaran. Proses pembelajaran seperti ini sesuai dengan pendapat Dwyer (dalam Asyhar, 2012) dan juga pendapat Mayer (2009) yang mengatakan bahwa multimedia interaktif memungkinkan siswa memproses informasi secara visual dan verbal sehingga memaksimalkan pemanfaatan potensial otak dalam belajar.

Ketuntasan individu dan klasikal yang diperoleh tentu tidak lepas dari peran alat bantu pembelajaran dan metode penyampaian informasi yang digunakan dalam hal ini penggabungan multimedia interaktif dan strategi inkuiri. Multimedia interaktif yang digunakan tentu saja yang sudah layak penilaiannya dari berbagai aspek penilaian, karena penggunaan multimedia dalam pembelajaran dapat mempertinggi proses dan hasil pengajaran yang berhubungan dengan taraf berpikir siswa (Sudjana, 2009).

Teori yang juga mendukung penggunaan multimedia interaktif dalam pembelajaran adalah teori kognitif dari piaget (Meyer 2009) menyimpulkan implikasi teori kognitif dalam multimedia yaitu : mampu mengarahkan perhatian siswa (attending), memberi pengharapan (ekspektation) dan retrival dengan tampilan animasi yang variatif, mampu menyajikan materi pelajaran dalam bentuk gambar atau ikon maupun teks dalam tampilan yang variatif sehingga pemahaman siswa pada suatu konsep lebih mendalam serta mampu memberikan isyarat tambahan dalam rangka mengingat kapabilitas berupa latihan soal yang interaktif.

Teori pemrosesan informasi menurut Gagne (dalam Sagala.2006) belajar adalah seperangkat proses kognitif yang mengubah sifat stimulasi lingkungan melewati pengelolaan informasi dan menjadi kapabilitas baru. Interaksi belajarnya melalui stimulus kondisi eksternal dari pendidik yang dapat direspons kondisi internal dan proses kognitif siswa. Berdasarkan teori tersebut maka dapat dikatakan bahwa pembelajaran dengan bantuan media yang sifatnya audio dan visual akan memberikan stimulus yang akan mempengaruhi siswa dalam proses belajar sehingga dapat membantu siswa memindahkan informasi dari memori jangka pendek ke memori jangka panjang.
Proses pembelajaran dengan menggunakan multimedia interaktif merupakan stimulus yang akan mempengaruhi siswa dalam proses pembelajaran yang memberi efek tersimpannya informasi dalam memori jangka panjang. Setiasih (2012) mengatakan bahwa prestasi belajar siswa mengalami peningkatan dengan pembelajaran menggunakan multimedia interaktif khususnya pada pokok bahasan ekosistem. Hal ini juga didukung oleh pendapat Aina (2013) bahwa pemanfaatan multimedia interaktif dalam pembelajaran IPA - Biologi dapat meningkatkan kemampuan kognitif siswa dan juga terjadi interaksi yang baik.

Ketuntasan individual dan klasikal yang baik tentu saja merupakan salah satu efek positif dari pembelajaran menggunakan media interaktif yang dipadu strategi inkuri, dan ini sejalan dengan kesimpulan Wibowo(2013) bahwa penggunaan multimedia interaktif dalam proses penyampaian materi struktur dan fungsi jaringan tumbuhan dapat membantu kualitas pembelajaran biologi.

\section{Hasil belajar Keterampilan/Psikomotor}

Pada penelitian ini aspek psikomotor yang diamati adalah berhubungan dengan kemampuan siswa menggunakan multimedia interaktif, mengkomunikasikan materi dan praktik. Berdasarkan hasil analisis data diperoleh persentase ketuntasan 100 $\%$ untuk masing-masing pertemuan. Adanya variasi nilai pada pertemuan pertama sampai ke empat disebabkan pada pertemuan pertama siswa masih ada yang belum memahami cara penggunaan media tetapi dengan memberikan penjelasan cara penggunaan media disertai petunjuk penggunaan yang dapat dibaca siswa dirumah dan pada pertemuan berikutnya tidak lagi mengalami masalah. Sehingga dapat disimpulkan bahwa semua siswa mampu menggunakan media interaktif dalam proses pembelajaran. Selain itu pada keterampilan mengkomunikasikan materi siswa juga mampu dengan baik mengkomunikasikan materi melalui cara mengajukan pendapat, bertanya dan mempresentasikan hasil kerjanya.

Hasil belajar psikomotor ini juga didukung dengan hasil penilaian keterbacaan media serta minat siswa yang sangat merespon positif penggunaan media inetarktif dalam pembelajaran. Tingginya hasil belajar psikomotor ini tentu saja bukan merupakan faktor dominan dalam pembelajaran, hal ini bisa dilihat pada hasil pengamatan aktivitas siswa yang merata antara kegiatan menggunakan media, berinteraksi dengan guru, bekerja mandiri dan berkelompok.

Strategi pengajaran inkuiri merupakan salah satu pendekatan mengajar yang guru hanya berfungsi sebagai fasilitator dimana siswa menemukan sendiri jawaban dari berbagai permasalahan yang diungkapkan. 
Guru hanya bersifat membantu siswa memecahkan masalah bersama-sama hal ini sesuai dengan teori Scaffolding dari Vygostky (Slavin, 2011) siswa perlu dibantu hingga sampai pada ZPD (zona proxima development).Dalam hal ini siswa menemukan pertanyaan yang terungkap serta tersaji dari media kemudian melakukan eksplorasi materi melalui media untu menemukan jawabannya selanjutnya diperkuat dengan bantuan lembar kerja siswa dan pada setiap akhir materi disediakan tes formatif interaktif untuk memperkuat retensi siswa.

Definisi sederhana dari pembelajaran meliputi: (1) pembelajaran membantu peserta didik untuk memperoleh pengetahuan dan keterampilan baru, (2) pembelajaran utama terdiri dari memberitahu, menunjukkan, membimbing siswa dalam tugas-tugas kinerja dan kemudian mengukur hasil (Singer, Murphy, \& Hines, 2003). Aktivitas pembelajaran dengan pengamtan, dan eksperimen tersebut mengubah paradigma siswa terhadap biologi, biologi merupakan ilmu yang sangat berguna bagi kehidupan, biologi pelajaran menyenangkan, hal tersebut terlihat dari respon positif siswa jika pembelajaran selanjutnya menggunakan pembelajaran dengan bantuan multimedia interaktif.

\section{Hasil belajar kompetensi sikap spiritual-sosial}

Hasil belajar afektif yang diamati berhubungan dengan kemampuan siswa dalam spiritual, disiplin, dan rasa tanggung jawab. Berdasarkan hasil analisis data yang dilakukan pengamat selama proses pembelajaran dari dua orang pengamat diketahui bahwa siswa memiliki kecendrungan mengalami peningkatan sikap spiritual yang baik. Ketuntasan tersebut dapat terwujud karena indikator-indikator sikap dilatihkan dalam pembelajaran, sebagai contoh adalah siswa dibiasakan untuk mengucapkan salam pada saat akan memulai kegiatan, sikap ini memang dibiasakan dalam proses pembelajaran. Hal tersebut sesuai dengan pendapat Mulyasa (2013) pembentukan sikap atau karakter memang tidak bisa secara tiba-tiba atau terbentuk dalam waktu singkat, tapi indikator perilaku dapat dideteksi secara dini oleh guru. Jika merujuk pada hasil analisis aktivitas siswa dan juga minat siswa dapat dikatakan bahwa siswa berperan aktif dalam proses pembelajaran, memiliki keterampilan yang baik dalam mengkomunikasikan hal-hal yang relevan dengan pembelajaran. Hal ini menunjukkan bahwa secara keseluruhan keterampilan sosial yang diamati tercapai oleh siswa . Hasil ini tentu saja sejalan dengan pendapat Slavin (2011) pengajaran melibatkan perolehan tandatanda melalui pengajaran dan informasi orang lain.

Perkembangan melibatkan penghayatan anak terhadap tanda-tanda ini sehingga sanggup berpikir dan memecahkan masalah tanpa bantuan orang lain. Jika kita hubungkan dengan keterampilan afektif yang diamati maka dapat dikatakan bahwa siswa harus memiliki sikap yang baik dalam bekerja sama sehingga mampu memecahkan permasalahan yang dihadapi dalam belajar.

Penggabungan penggunaan media dan lembar kerja membuat keterampilan afektif siswa tumbuh dengan baik, hal ini tentu sesuai dengan pendapat Vygotsky (Slavin, 2011) bahwa siswa dapat belajar mandiri dan dengan sedikit bantuan dari guru untuk memperoleh informasi tentang suatu hal.Jadi dapat disimpulkan bahwa pembelajaran tidak lepas dari peran guru tetapi tidak dominan dalam pembelajaran sehingga pembelajaran terpusat pada siswa.

Setelah melalui proses dari validasi hingga implementasi pada sampel terbatasmaka dapat disimpulkan bahwa perangkat pembelajaran berbasis TIK yang berupa media pembelajaran interaktif valid dari segi kelayakan, praktis dari segi pembelajaran dan efektif dalam segi peningkatan hasil belajar sehingga media yang dikembangkan layak untuk digunakan dalam proses pembelajaran untuk cakupan yang lebih luas.

\section{Keterampilan berpikir kritis}

Keterampilan berpikir kritis yang dilatih dalam penelitian ini meliputi lima indikator yaitu (1) merumuskan masalah, (2) melakukan evaluasi ,(3) melakukan deduksi, (4) memberikan kesimpulan, (5) memberikan argumen. Dari hasil analisis data dapat diketahui bahwa semua indikator keterampilan berpikir kritis dikategorikan tuntas, faktor ketuntasan ini didukung oleh struktur penyajian media yang menggunakan pola belajar inkuiri yang tersusun dalam rencana pelaksanaan pembelajaran, dimana pada media disediakan pertanyaan-pertanyaan yang membutuhkan proses inkuiri untuk menemukan jawabannya serta dibantu dengan keberadaan lembar kerja siswa sehingga proses belajar siswa menjadi terarah. Hal ini dapat dikatakan bahawa perangkat yang dikembangkan memiliki pengaruh positif dan baik untuk melatih keterampilan berpikir kritis siswa.

Hasil ini sejalan dengan penelitian Ching dan Fook (2013) yang menyimpulkan bahwa multimedia dapat meningkatkan dan memfasilitasi kemampuan berpikir kritis siswa. Penggunaan multimedia ini tentu sejalan dengan teori yang diungkapkan oleh vygotsky (dalam Slavin 2011) bahwa pembelajaran melibatkan perolehan tanda-tanda melalui pengajaran dan bantuan orang lain. Hubungan antara teori ini dengan multimedia untuk melatih keterampilan berpikir kritis adalah siswa akan belajar melalui gambar-gambar yang akan menimbulkan pertanyaan sehingga akan membuat 
siswa ingin mengetahui penjelasan yang benar tentang suatu proses atau peristiwa.

Metode pembelajaran yang menggabungkan antara multimedia dengan strategi inkuiri tentu sesuai dengan pendapat Kardi (2013) yang menyatakan pada dasarnya inkuiri dipandang sebagai proses untuk menjawab pertanyaan dan memecahkan masalah. Dengan bantuan multimedia siswa dihadapkan pada fakta sehingga akan muncul pertanyaan yang relevan dengan materi, hal inilah yang akan membantu melatih keterampilan berpikir kritis siswa tersebut. Peran guru hanya menggiring dengan pertanyaan yang tersedia pada media . Hal ini seperti pendapat (Ristanto, 2010) mengatakan dalam pembelajaran inkuiri terbimbing peran guru adalah memberikan pertanyaan-pertanyaan dalam proses penemuan.

Pembelajaran dengan strategi inkuiri berbantuan multimedia akan memberi manfaat yang banyak dalam pembelajaran terutama berubahnya strategi penyampaian informasi menjadi penggalian informasi, pembelajaran terpusat pada siswa, siswa lebih mengerti akan konsep dan ide, siswa akan terdorong untuk berpikir dan berinisiatif serta menumbuhkan kepercayaan diri (Mbulu, 2011).

Keberadaan media interaktif sebagai alat bantu tentu akan membuat siswa berpikir reflektif berdasarkan nalar sehingga mampu menentukan apa yang diyakini (Ennis, 1996). Multimedia interaktif yang dipadukan dengan strategi inkuri dalam pembelajaran akan membuat siswa belajar dari pengalaman piktorial/gambar untuk selanjutnya akan merekonstruksi gambar-gambar tersebut menjadi suatu kesimpulan yang utuh melalui proses pencarian data dan fakta. Hal ini sesuai pendapat Bruner (dalam Arsyad, 2013) yang mengatakan bahwa ada tiga tingkatan utama modus belajar yaitu pengalaman langsung (enactive), pengalaman gambar (iconic) dan pengalaman abstrak (symbolic).

\section{Minat Siswa}

Hasil pengolahan data minat siswa menunjukkan rata-rata skor 3,9 setelah ditafsirkan dengan skala penilaian oleh Keller (1987) dikategorikan baik. Hal ini merepresentasikan bahwa siswa memiliki minat yang baik untuk belajar dengan menggunakan media pembelajaran interaktif. Kesimpulan ini diperoleh dari angket minat yang diisi sendiri oleh siswa yang meliputi aspek perhatian, relevansi, percaya diri dan kepuasan.

Respons positif tersebut menunjukkan bahwa media pembelajaran yang dikembangkan dapat membuat siswa merasa senang mengikuti mata pelajaran biologi. Menurut Heinich, dkk (1993) proses pembelajaran menggunakan multimedia mencakup tiga perspektif pada teori pembelajaran, yaitu behaviorist perspective, cognitive perspective dan contruktivis perspective. Adanya stimulus dari media membuat siswa berinteraksi sehingga terjadi proses pembelajaran (Sagala, 2006). Seperti yang diungkapkan (Budiningsih, 2005) bahwa penggunaan program pembelajaran teaching machine akan memunculkan respon siswa untuk belajar.

Beberapa hal yang menjadi alasan siswa menjadi merasa senang belajar dengan menggunakan media pembelajaran interaktif berbasis inkuiri pada mata pelajaran biologi adalah dapat dilihat dari beberapa indikator diantaranya adalah materi yang dipaparkan menjadi lebih jelas karena dilengkapi dengan gambargambar, animasi dan video, langkah-langkah suatu proses materi mudah dipahami, siswa dapat berdiskusi dengan temannya dalam satu kelompok. Proses belajar siswa merupakan implikasi yang diberikan oleh teori behavioristik dalam penggunaan multimedia interaktif (Budiningsih, 2005). Hal ini sejalan dengan hasil penelitian Miyarso (2009) yang menyatakan bahwa multimedia interaktif mampu memotivasi siswa pada saat proses pembelajarannya. Respon positif siswa terhadap pembelajaran ini sesuai dengan pendapat Meyer (2009) bahwa implikasi dari teori kognitif dalam multimedia yaitu: (1) mampu mengarahkan perhatian (attending), pengharapan (ekspektasi) dan retrival dengan tampilan animasi yang variatif (2) mampu menyajikan materi pelajaran dengan bentuk gambar dan sandi (icon), maupun dengan teks dan tampilan yang variatif sehingga pemahaman siswa pada suatu konsep lebih mendalam, (3) mampu memberikan isyarat tambahan dalam rangka mengingat kapabilitas berupa latihan soal yang interaktif.

Hasil penelitian ini juga diperkuat dengan pernyataan Ardiani (2012) yang mengatakan bahwa respon siswa sangat positif terhadap pembelajaran menggunakan multimedia interaktif. Wiyono (2009) juga menyatakan dalam hasil penelitiannya $87 \%$ dari sampel merespon positif model pembelajaran multimedia interaktif yang digunakan. Selain itu Lopez (2013) juga menyimpulkan bahwa media pendidikan merupakan kunci untuk mengimprovisasi, memotivasi dan menarik perhatian siswa serta mendukung proses belajar dan mengajar dalam konteks pendidikan.Selain itu sesuai juga dengan hasil penelitian Priliyati (2012) yang mengatakan multimedia interaktif layak dan menarik minat siswa untuk belajar. Hubungan positif antara ketertarikan siswa dengan multimedia interaktif dan proses belajar karena di dalam media tersebut mengandung unsur-unsur yang dapat membuat siswa termotivasi belajar. Hal ini sesuai pendapat Hamalik (2003) terdapat lima unsur yang terkait dalam proses belajar yaitu: motivasi belajar, bahan belajar, bantuan 
belajar (media), suasana belajar dan kondisi subyek belajar belajar.

\section{KESIMPULAN}

A. Simpulan

Multimedia interaktif yang dikembangkan telah layak digunakan untuk meningkatkan hasil belajar dan melatihkan keterampilan berpikir kritis siswa.

\section{B. Saran}

Dapat dikemukakan oleh peneliti berdasarkan penelititan yang telah dilakukan meliputi:1) Persiapan yang matang dan pengelolaan waktu yang optimal untuk setiap kegiatan KBM jika menggunakan pembelajaran berbasis TIK sehingga semua siswa aktif dalam pembelajaran. 2) Untuk kemudahan, sebelum proses pembelajaran softcopy atau hard copy media diberikan kepada siswa yang disertai petunjuk penggunaan yang lengkap.

\section{REFERENSI}

Aina, M. (2013). "Efektifitas pemanfaatan multimedia interaktif pembelajaran IPA- Biologi dalam meningkatkan motivasi belajar siswa pria dan wanita SMP 19 kota Jambi”. Prosiding Semirata FMIPA Universitas Lampung.

Ali, M. (2009). "Pengembangan media pembelajaran interaktif mata kuliah medan elektromagnetik". Jurnal Edukasi@Elektro. Vol.5 No.1, pp.11-18m.

Arikunto, S. (2012). Dasar- dasar evaluasi pendidikan.. Jakarta : Bumi Aksara.

Arsyad, A. (2013). Media pembelajaran. Jakarta : Raja Grafindo Persada.

Baharudin dan Nurwahyuni. (2010). Teori belajar dan pembelajaran. Jakarta : AR-Razzmedia.

Borich, G. D. (1994). Observation skills for effective teaching. Engelwood Clift: MacMillan Publishing Company.

Budiningsih, A. (2005). Belajar dan pembelajaran.. Jakarta : Rineka Cipta.

Depdikbud. (2013a). Permendikbud No. 81a Tentang Implementasi Kurikulum Pedoman Umum Pembelajaran. Jakarta: Depdikbud

Eggen, P and Kauchak, D. (2012). Strategi dan model pembelajaran, mengajarkan konten dan keterampilan berpikir. Jakarta : Indeks Permata Puri Media

Ennis, R.H. (1996). Critical thinking. Illionis, Prentice Hall

Fuad, N.M. (2013). Pengembangan media pembelajaran animasi berbasis inkuiri pada materi sistem ekskresi manusia untuk melatih keterampilan berfikir kritis (Tesis magister pendidikan tidak dipublikasikan). Universitas Negeri Surabaya Surabaya

Groundlound, N.E. (1982). Construction achievment test, third edition. Engelwood Clift : Prentice Hall.Inc

Hake, Richard, R. (1999). Analyzing changelgain scores. USA. Dept of Physics. Indiana University

Heinich, R., Molenda, M., and Russel, J.D. (1993). Instructional media and the new technologies of instruction. New York : Jhon Willey and Sons

Hii Sii Ching, and Fong Soon Fook. (2013). "Effects of multimedia-based graphic novel presentation on critical thingking among students of different learning aproach. The Turkish Online Journal of Educational Technology. Vol.12 No.4, pp.63- 65

Kardi, S. (2002). Mengembangkan Tes Hasil Belajar. Surabaya: Universiy Press

Keller, J.M. (1987)."Development and use of the ARCS model of moivaional design". Journal of instructional development. Vol.10 No.3, pp. 19

Milovanovic, M., Obradovic, J., and Milajic, A. (2013). "Application of interactive multimedia tools in teaching mathematics-example of lesson from geometry." TOJET: The Turkish Online Journal of Educational Technology . Vol.12 No.1, pp. 29-30

Meyer, R.E. (2009). Multimedia learning " prinsipprinsip dan aplikasi". Yogyakarta: Pustaka Pelajar

Mulyasa, H.E. (2013). Pengembangan dan implementasi kurikulum 2013. Bandung: Remaja Rosdakarya.

Munadi, Y. (2008). Media pembelajaran, sebuah pendekatan baru. Jakarta : Gaung Persada

Nur, M., Wikandari., dan Sugiarto. (2004). Teori belajar. Surabaya : University Press

Ristanto, H.R. (2010). Pembelajaran berbasis inkuiri terbimbing dengan multimedia dan lingkungan riil ditinjau dari motivasi berprestasi dan kemampuan awal (Tesis pascasarjana tidak dipublikasikan) Universitas Sebelas Maret. Surakarta

Sagala, S.(2006). Konsep dan makna pembelajaran.. Bandung : CV.ALFABETA,

Samodra, D.W., Suhartono, V., dan Santosa, S. (2009). "Multimedia pembelajaran reproduksi manusia". Jurnal Teknologi Informasi. Vol.5 No.2, pp.706-709 
Singer, A. J., Murphy, M., \& Hines, S. M. (2003). Teaching to learn, learn to teach. London: Lawrence Erlbaum Associates.

Slavin, R. E. (2011). Educational psycology. Jakarta : PT.Indeks

Smaldino, S.E., James, D., Russell, D.J., Heinich, R., and Molanda, M. (2011). Instructional technology and media for learning. New Jersey : Pearson

Sunardi., dan Santosa, S. (2010). "Multimedia pembelajaran tata surya dengan pendekatan inkuiri bagi kelas x smk". Jurnal Teknologi Informasi. Vol.6 No.1,pp. 41-42

Sutarno. 2011. "Penggunaan multimedia interaktif pada pembelajaran pada pembelajaran medan magnet untuk meningkatkan keterampilan generik sains mahasiswa". Jurnal Exacta. Vol.11 No.1, pp. 60-66

Sutrisno. (2012). Kreatif mengembangkan aktivitas pembelajaran berbasis TIK. Jakarta :Referensi

Wahono, S.R. (2006). Penilaian Media. http//Romisatriowahono.net diakses 28 juni 2014

Wahyudin, Sutikno dan A .Isa. (2010). "Kefektifan pembelajaran berbantuan multimedia menggunakan metode inkuri terbimbing untuk meningkatkan minat dan pemahaman siswa". Jurnal Pendidikan Fisika Indonesia. Vol 6, pp. 58-62

Walter ,D., Carey, L., and Carey, O.J. (2009). The systematic design of instruction. New Jersey : Pearson

Wicaksono, A. (2012). Pengembangan model media belajar interaktif visual berbasis film dokumenter bertema lokal dalam materi antrophosper pada pembelajaran geografi kelas xi di SMAN 7 (Tesis magister tidak dipublikasikan) Universitas Lambung Mangkurat, Banjarmasin

Widayati, W., Kasmui, S., dan Sukaesih. (2014). "Pengembangan multimedia interaktif sebagai media pembelajaran ipa terpadu pada tema sistem gerak pada manusia". Unnes Science education journal. Vol.3 No.2, pp. 538-540

Wiyono, K., A.Setiawan., dan A. Suhadi. (2009). "Model pembelajaran multimedia interaktif relativ khusus untuk meningkatkan keterampilan generik sains siswa SMA". Jurnal Pendidikan IPA. Vol .3 No.1, pp. 1-12 